\title{
Extent And Patterns Of Drug Use Among Persons With Disabilities In Kenya
}

\author{
Beatrice Kathungu ${ }^{1}$, Lydia Mwaura², Beth Wambugu³. \\ ${ }^{1}$ Department of Psychology, Kenyatta University, Nairobi, Kenya; ${ }^{2}$ Centre \\ for Public Health Research, Kenya Medical Research Institute, Nairobi, \\ Kenya; ${ }^{3}$ Department of Education, Moi University, Eldoret, Kenya.
}

Correspondence email: bkathungu@gmail.com

\begin{abstract}
Background: Although some data existed suggesting that there was high prevalence of drug use among the general population in Kenya with 39-48\% of 15-65 year olds having used alcohol and at least one other substance, there was a general absence of comprehensive data on the extent of drug use among Persons With Disability (PWD). The current study therefore sought to fill the gap by establishing the extent and patterns of drug use among PWD.
\end{abstract}

Methods: This was a cross-sectional descriptive study targeting PWD based in learning institutions as well as within the community in three selected regions of Kenya (Nairobi, Coast and Central). A combination of stratified and purposive sampling was used to identify a sample of 486 PWD. Data was collected using a structured questionnaire and quantitatively analysed using descriptive statistics, namely, frequencies and percentages to show the extent and patterns of drug use among PWD.

Results: The findings revealed that $35 \%$ of the respondents had used some form of drug, with a majority having done so between the ages 15-19 (43.3\%). Further, $13.6 \%$ had used at least one substance in the past year, $7.4 \%$ in the past month and $3.9 \%$ had used drugs daily. The type of drug used were alcoholic beverages $(28.2 \%)$, tobacco products $(19.6 \%)$, khat (miraa/muguka) (14.8\%) and marijuana (9.2\%).

Conclusion:The findings proved that compared to the general population, the prevalence of drug use among PWD is higher for most of the drugs. The findings point to an urgent need for policies to guide Alcohol and Drug Abuse (ADA) prevention and treatment programmes targeting PWD. 


\title{
ابعاد و أنماط تعاطي المخدرات بين الأشخاص ذوي الإعاقاتفي كينيا
}

\author{
بياتريس كاثونغو \\ جامعة كينياتا

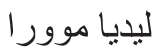 \\ المعهد الكيني للأبحاث الطبية \\ جامعة مووي
}

الملخص:

لمحة عن الموضوع: رغم أن البيانات التي كانت متوفرة كانت توحي بانتشار كبير لتعاطي المخدر ات بين

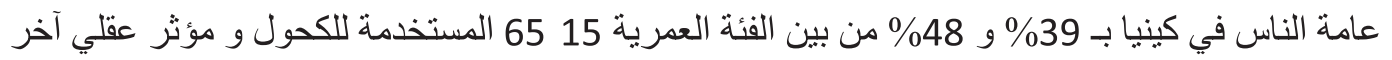

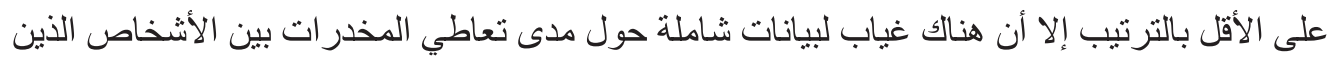

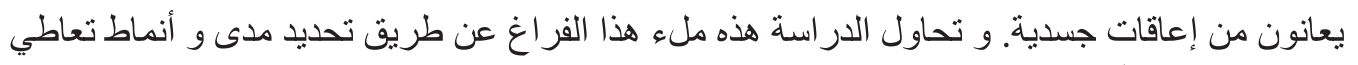

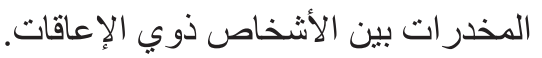

الطريقة:تعتبر هذه الدر اسة وصفية متعددة الأطر اف و تستهدف ذوي الإعاقات في المؤسسات التعليمية و كذا

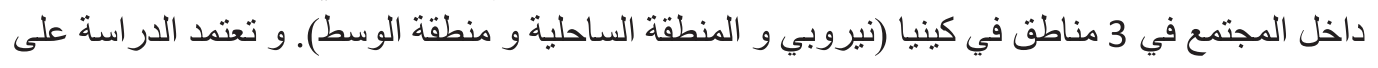
الطريقتين التقيم الطبقي و المضو عي بغية تحديد عينة قو امها 486 شخص ذو ذو إعاقة و تم تجميع البيانات

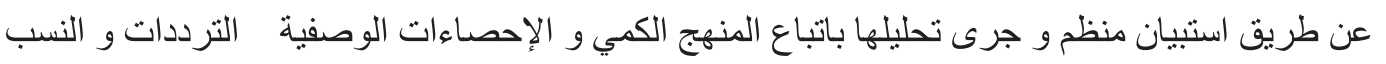

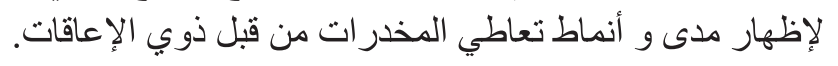

النتائج:بينت النتائج أن 35\% من بين المشاركين في الإستبيان تعاطو ا مخدر ات و الغالبية قامو ا بذلك في

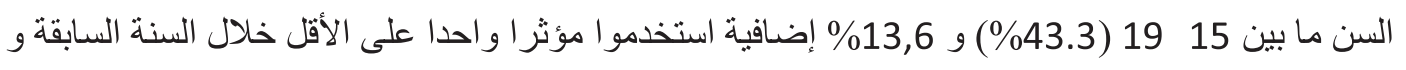

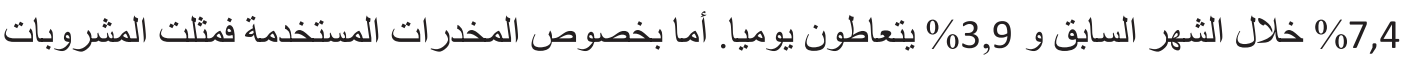
الكحولية نسبة 28,2\% و التبخ نسبة 19,6\% و القاط (مير ا/موجوكا) نسبة 14,8\% و و الماريجو انا بنسبة $\% 9,2$

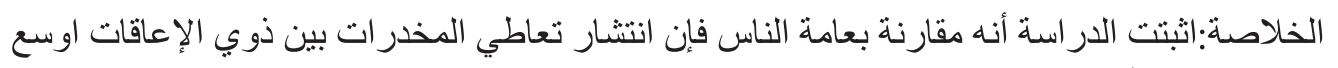

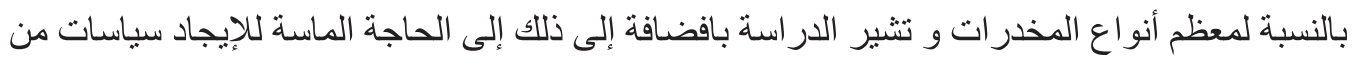

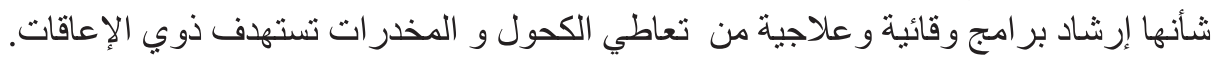

Keywords: Persons with disabilities, Alcohol and drug use, Patterns of drug use 


\section{Introduction}

In Kenya, an estimated three million ( $8 \%$ ) people have some form of disability $^{2}$ which influences the way they conduct their daily functions, including dealing with myriad challenges associated with their disability.

The Kenyan Government has over the years made significant progress in its effort to promote the rights of PWDs. This is evidenced by, among others, the enactment of the Disability Act ${ }^{3}$ which seeks to promote the rights and wellbeing of PWDs in Kenya. In addition, the Ministry of Devolution and National Planning has been mandated to look into the issues related to the needs of PWDs in Kenya. Other efforts are seen in the initiatives by the Kenyan Ministry of Education to enhance the wellbeing of children with disabilities by having them placed in mainstream schools. Such efforts may be undermined if PWDs, who are already vulnerable, suffer the effects of ADA.

Some literature from the rest of the world ${ }^{4}$ suggests that PWDs are affected by ADA just like others in society. However there is a high incidence of substance abuse symptoms reported by some disability groups such as those with quadriplegia and traumatic brain injury. It's not clear however, whether the same applies to Kenya.

In Kenya there have been efforts to manage drug related problems that have been on the increase, the government's commitment is seen in the enactment into law of the Alcoholic Drinks Control Act ${ }^{5}$ which seeks to regulate the production, sale and consumption of alcohol. The push for this law was driven by evidence that there was a high prevalence of drug use among the general Kenyan population, with some study findings ${ }^{1}$ revealing that $8 \%$ of 10 -year-olds and $13 \%$ of 14 -year-olds had used alcohol and other substances, while $39 \%$ of 15 -year-olds and $48 \%$ of 65 -year-olds had used alcohol and other substances.

A similar study ${ }^{6}$ found that $40 \%$ of the respondents indicated alcohol use to be very high in the Central Province, while a related study found a lifetime prevalence of $37.1 \%$ among the general public. ${ }^{7}$ While this data was on the general Kenyan population, there was a general absence of data on drug use among PWDs. It was not clear whether the prevalence of drug use among such populations mirrored that of the general public. This situation had been articulated by a NACADA workshop ${ }^{8}$ which recommended the need for research to investigate if PWDs were in any way affected by the drug use problem as observed with the general Kenyan public. Such data would guide policy development to address the unique needs of such populations. It was the need to fill this knowledge gap that motivated this study which 
was financed through a research grant from NACADA, the body mandated by the Kenyan Government to oversee all matters pertaining to policies and programmes related to drugs.

\section{Objectives of the study}

The broad objective of the study was to find out the extent and patterns of drug use among PWDs (in the community as well as in learning institutions) with the following specific objectives:

1. To establish the lifetime prevalence of drug use among PWDs.

2. To find out the specific types of drugs used by PWDs.

3. To establish the frequency of drug use among PWDs.

4. To find out the age at first use of drugs among PWDs.

\section{Methods}

This was a cross-sectional descriptive study that sought to find out the extent and patterns of drug use among PWDs in Kenya. The target population was persons with various types of disabilities (namely; physical, visual, hearing and intellectual impairment) based on learning institutions (secondary schools, vocational institutions, and post secondary institutions) as well as those based within the community.

The study site was in three selected regions in Kenya (namely; Nairobi, Coast and Central, which were provinces according to the former Kenyan Constitution). Nairobi and Coast were selected because previous studies had indicated a high prevalence of drug availability among the general public there, ${ }^{1}$ hence the need to find out if PWDs living in these areas were also vulnerable to drug use. Central was selected because, in addition to a high prevalence of alcohol use reported among the general public ${ }^{6}$ it hosted most of the learning institutions that catered for persons with different disabilities targeted in this study.

In order to achieve a sample that was representative of the PWDs within and outside of learning institutions (community based), as well as the various categories of disability as per the study objectives, a combination of stratified and purposive sampling was used. Stratified random sampling was used for respondents based in institutions to ensure representation of the regions, the various categories of disability as well as the PWDs within institutions.

On the other hand, purposive sampling, specifically snowballing, was used 
for the community-based population of PWDs who were considered hard to reach. The inclusion and exclusion criteria included the presence/absence of a disability, age, and location. Only consenting persons with certain types of disability (namely; physical, visual, hearing and mental), aged between 10 and 65, and found within the three regions of Kenya were included. Excluded from the study were persons without disability or with other types of disability outside of the four mentioned above. Similarly, PWDs aged below 10 and above 65 , those outside of the three study regions, as well as those who did not consent were excluded.

In determining the sample size, since the prevalence of alcohol, drug and substance abuse by persons with disabilities in Kenya was not known, 50\% was assumed. To estimate the true prevalence to within five percentage points with $95 \%$ confidence, a minimum sample of 385 was required. The following formula by Fisher et al (1998) ${ }^{9}$ was used for sample size estimation:

$$
\mathrm{n}=\mathrm{Z}^{2} 1-\alpha / 2 \mathrm{p}(1-\mathrm{p})
$$

$d^{2}$

Where: $\mathrm{n}=$ Sample size to be determined, $Z_{1}-\alpha / 2=$ Standard errors from the mean corresponding to $95 \%$ confidence level, $\mathrm{P}=$ Prevalence of alcohol, drug and substance abuse among disabled persons, $\mathrm{d}=$ Absolute precision (margin of error).

Considering the uniqueness of PWDs, it was crucial to factor in the possibility of finding PWDs in the sample that would not be able to participate in the study due to the severity of their disability. It was therefore judged necessary to over sample up to a sample size of 500. The final sample from whom data was gathered was 486 .

Data was collected using a structured questionnaire which had sections on socio-demographics, lifetime use of drugs, specific types of drugs used, frequency of use for specific drugs and the age at first use.

Prior to conducting the field work, research assistants were recruited and taken through an intensive training which involved being inducted on the study objectives and process as well as being trained on how to use the various instruments to collect data from the different categories of PWDs in a respectful and non-stigmatising manner considering their vulnerability.

Prior to the final study, a pilot study was carried out using respondents similar to those targeted but who were excluded from the final study. The feedback from the pilot study was used in the revision of the instruments to enhance the validity and reliability of the study. A 'test-retest reliability method' was 
used to check the reliability of the instrument. It yielded a reliability index of 0.75 which was considered adequate in line with the recommendations of researchers. ${ }^{10}$

The field work period was from December 2012 to February 2013. Only those participants who consented to participate in the study were included. For participants who were aged below 18 years, and who were in boarding schools, consent was given by the school administration on behalf of the parents. However, in addition, informed consent was further sought from each participant prior to inclusion in the study. Prior to conducting the study, ethical clearance was obtained from the Kenyatta University Ethics Review Committee and a permit and letter of authority to conduct research were obtained from the National Commission for Science Technology and Innovations (Approval No. NCST/RRI/12/1/SS/928). Data was collected by means of self-administered questionnaires which were brailed for those with visual impairment. A sign language interpreter was part of the research team to facilitate communication with those with hearing impairment. The data was later cleaned, coded and entered into the Statistical Package for Social Sciences (SPSS) version 17.0 software for analysis. Data was quantitatively analysed using descriptive statistics, namely, frequencies and percentages to show the extent and patterns of drug use.

\section{Results}

More than half of the respondents were male $(60.9 \%)$, the majority were below 20 years, with most being single (83\%). The majority were students $(73.0 \%)$, while $13.2 \%$ were employed (self employed or otherwise), with $5.6 \%$ being unemployed. In terms of disability, most of the respondents were physically disabled (28.6\%), while $20.4 \%$ were visually impaired.

Data on lifetime use, as shown in Table 1, revealed that $35 \%$ of the respondents had used drugs while 53\% said they had never used drugs. Some 12\% did not respond. It is possible that they could be in the category of users but lacked the courage to admit it, considering this was a sensitive question.

Table 1. Life time use of drugs

\begin{tabular}{|l|c|c|} 
& Frequency & Percent \\
\hline Yes & 170 & 35 \\
\hline No & 259 & 53.3 \\
\hline Total & 429 & 88.3 \\
\hline No Response & 57 & 11.7 \\
\hline Total & $\mathbf{4 8 6}$ & $\mathbf{1 0 0}$ \\
\hline
\end{tabular}


In terms of types of drugs used, the findings indicated that majority $(28.2 \%)$ had used alcoholic beverages, followed by tobacco products $(19.6 \%)$, khat $(14.8 \%)$ and marijuana $(9.2 \%)$. This is illustrated in Table 2.

Table 2. Types of drugs used

\begin{tabular}{|l|c|c|}
\hline & Frequency & Percent \\
\hline Tobacco Products & 95 & 19.6 \\
\hline Alcoholic Beverages & 137 & 28.2 \\
\hline Marijuana & 45 & 9.2 \\
\hline Khat/Miraa/Muguka & 72 & 14.8 \\
\hline Heroine & 27 & 5.6 \\
\hline Cocaine & 27 & 5.6 \\
\hline Inhalants & 35 & 7.2 \\
\hline Prescription & 30 & 6.2 \\
\hline Synthetic & 18 & 3.7 \\
\hline & & 100.0 \\
\hline n= 486 & &
\end{tabular}

In terms of frequency of use, the study findings indicated that $13.6 \%$ of the respondents had used at least one substance in the past one year, $7.4 \%$ in the past one month (current use) and 3.9\% were using at least one substance daily. Considering that learning institutions are supposed to be safe havens with restrictions of access to drugs, it was found necessary to disaggregate the data by location of respondents (institution-based or community-based). This would help in giving a picture of the drug use problem for PWDs within learning institutions, which would be crucial in informing institutional policies on drugs. The findings revealed that drug use was reasonably high in learning institutions with $33.8 \%$ reporting as having used drugs, almost rivalling that of community-based respondents (38.2\%). Similarly, the category for past one year use for learning institutions (13.5\%) was almost on par with that of community-based respondents (13.7\%). These findings are illustrated in Table 3. 
Table 3. Frequency of use by location of respondents

\begin{tabular}{|c|c|c|c|c|}
\hline Frequency of use & $\begin{array}{l}\text { Location of } \\
\text { respondents }\end{array}$ & Frequency & Percent & n \\
\hline \multirow[t]{3}{*}{$\begin{array}{l}\text { Use of at least one } \\
\text { substance }\end{array}$} & $\begin{array}{l}\text { Learning Institu- } \\
\text { tion-based respondents }\end{array}$ & 120 & $33.8 \%$ & 355 \\
\hline & $\begin{array}{l}\text { Community-based } \\
\text { respondents }\end{array}$ & 50 & $38.2 \%$ & 131 \\
\hline & Combined group & 170 & $35 \%$ & 486 \\
\hline \multirow{3}{*}{$\begin{array}{l}\text { Past one year use } \\
\text { of at least one } \\
\text { substance }\end{array}$} & $\begin{array}{l}\text { Learning Institu- } \\
\text { tion-based respondents }\end{array}$ & 48 & $13.5 \%$ & 355 \\
\hline & $\begin{array}{l}\text { Community-based } \\
\text { respondents }\end{array}$ & 18 & $13.7 \%$ & 131 \\
\hline & Combined group & 66 & $13.6 \%$ & 486 \\
\hline \multirow{3}{*}{$\begin{array}{l}\text { Current use of at } \\
\text { least one sub- } \\
\text { stance (past } 1 \\
\text { month) }\end{array}$} & $\begin{array}{l}\text { Learning Institu- } \\
\text { tion-based respondents }\end{array}$ & 18 & $5.1 \%$ & 355 \\
\hline & $\begin{array}{l}\text { Community-based } \\
\text { respondents }\end{array}$ & 18 & $13.7 \%$ & 131 \\
\hline & Combined group & 36 & $7.4 \%$ & 486 \\
\hline \multirow{3}{*}{$\begin{array}{l}\text { Daily use of at } \\
\text { least one sub- } \\
\text { stance }\end{array}$} & $\begin{array}{l}\text { Learning Institu- } \\
\text { tion-based respondents }\end{array}$ & 11 & $3.1 \%$ & 355 \\
\hline & $\begin{array}{l}\text { Community-based } \\
\text { respondents }\end{array}$ & 8 & $6.1 \%$ & 131 \\
\hline & Combined & 19 & $3.9 \%$ & 486 \\
\hline
\end{tabular}

Results for frequency of use for specific substances, using indicators of daily usage, use in the past one month and use in the past 12 months and synthetic drugs were the most frequently used in terms of daily use, followed by tobacco products. Alcoholic beverages and tobacco products led in terms of both past one month and use in the past 12 months. The findings further revealed that some of the PWDs were using more than one substance, indicating poly-substance use. These findings are further illustrated in Table 4. 
Table 4. Frequency of use for specific substances

\begin{tabular}{|l|c|c|c|c|c|c|}
\hline & $\begin{array}{l}\text { Used in 12 } \\
\text { months }\end{array}$ & \multicolumn{3}{l}{$\begin{array}{l}\text { Used in past 1 } \\
\text { month }\end{array}$} & \multicolumn{2}{l}{ Used daily } \\
& $\begin{array}{l}\text { Fre- } \\
\text { quency } \\
\text { n=486 }\end{array}$ & Percent & $\begin{array}{l}\text { Fre- } \\
\text { quency }\end{array}$ & $\begin{array}{l}\text { Per- } \\
\text { cent }\end{array}$ & $\begin{array}{l}\text { Fre- } \\
\text { quency }\end{array}$ & Percent \\
& n=486 & & n=486 & \\
\hline Tobacco Products & 27 & 5.6 & 14 & 2.9 & 12 & 2.4 \\
\hline Alcoholic beverages & 34 & 7.0 & 22 & 4.5 & 6 & 1.2 \\
\hline Marijuana & 13 & 2.7 & 11 & 2.3 & 2 & 0.4 \\
\hline Khat & 23 & 4.7 & 6 & 1.2 & 2 & 0.4 \\
\hline Heroin & 6 & 1.2 & 2 & 0.4 & 2 & 0.4 \\
\hline Cocaine & 2 & 0.4 & 2 & 0.4 & 1 & 0.2 \\
\hline Inhalants & 7 & 1.4 & 1 & 0.2 & 3 & 0.6 \\
\hline Prescription drugs & 9 & 1.9 & 3 & 0.6 & 6 & 1.2 \\
\hline Synthetic drugs & 5 & 1.0 & 1 & 0.2 & 13 & 2.7 \\
\hline
\end{tabular}

Data on age at first use revealed that the majority had first used drugs between the ages of 15- 19 (43.3\%), while some had used drugs as early as ages 5-9 years. The results are shown in Figure 1.

\section{Figure 1. Ages at first use of drug/s}

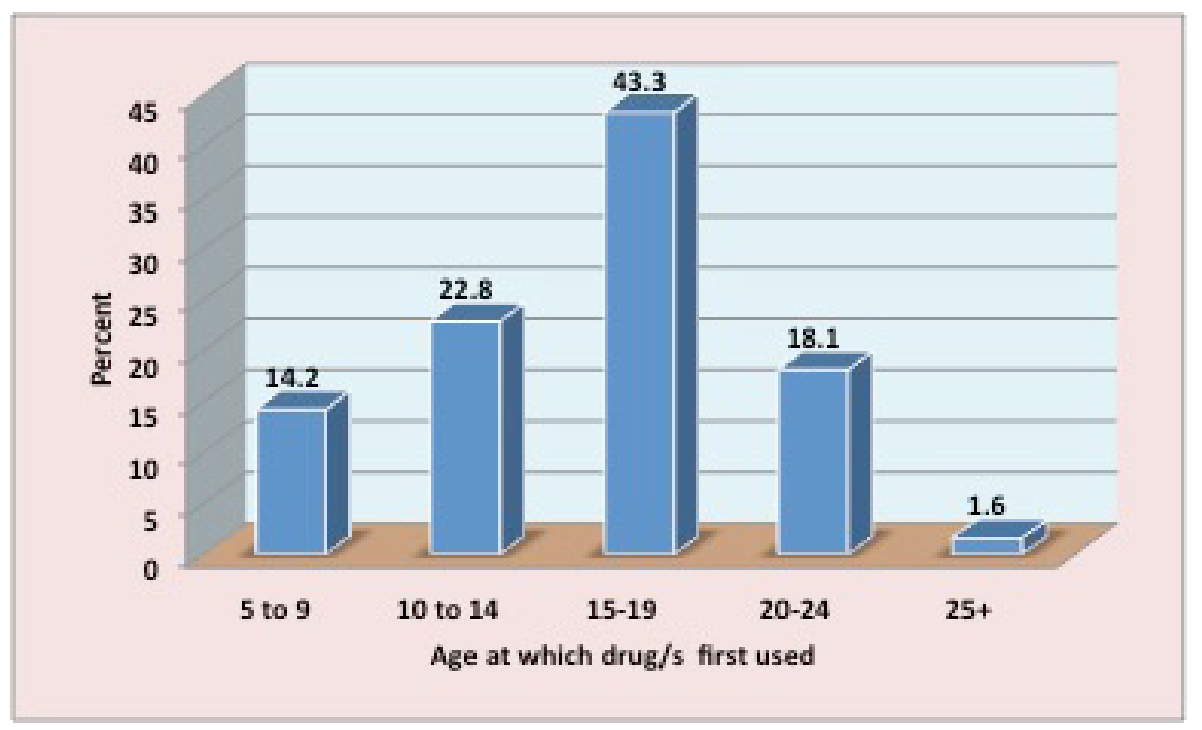




\section{Discussion}

The finding that on 35\% report ever having used drugs indicate that there is a high prevalence of alcohol and drug use among PWDs just as the general public. The finding is comparable to another study ${ }^{7}$ that found $37.1 \%$ lifetime prevalence among the general public. The findings of high levels of drug use among PWDs support the notion by researchers ${ }^{11,12}$ that PWDs are at a high risk of substance use due to myriad of factors including stigma, discrimination, health problems, alienation by society, and a lack of access to adequate and appropriate treatment services, among others. These findings also support those of another researcher ${ }^{13}$ who found that PWDs report higher incidence rates of Alcohol, Tobacco, and Other Drug (ATOD) use than their peers.

The finding that the current use of drugs is at $13.7 \%$ for the community-based respondents is worth noting. They suggest that indeed PWDs, like the general public, are affected by the problem of drug use which supports the notion that PWDs may be disproportionately experiencing alcohol and substance abuse rates that are 2-4 times that of the general population. ${ }^{14}$ This is coupled with the daily use findings of $6.1 \%$ for community-based respondents. These findings suggest that among PWDs are persons who may have drug use problems, possible addiction to one or more substances, and who may be spending substantial resources on drugs.

This is a paradox, considering that many PWDs may be already disadvantaged economically since functional limitations such as physical impairment act as barriers to obtaining employment for individuals with disabilities. ${ }^{15}$ Therefore, such drug use patterns may only serve to make them more vulnerable to the risks of health problems and entrapment into the cycle of poverty and its sequel. This is of concern considering that treatment for ADA (Alcohol and Drug Abuse) is an expensive undertaking. Treatment of PWDs who experience alcohol and drug abuse is even more expensive and involves inter alia, chemical dependency treatment, education, healthcare costs, including, but not limited to rehabilitation. ${ }^{16}$ It would also require modification of treatment facilities to facilitate accessibility for PWDs due to their unique needs. For these reasons, rehabilitation for PWDs is often inadequate, geographically inaccessible and expensive. The implications then are that if PWDs are to benefit from treatment and rehabilitation programmes, there is a need to factor in issues of accessibility and affordability into such programmes.

The findings further revealed that drug use was reasonably high in learning institutions with $33.8 \%$ reporting having ever used drugs, almost rivalling that of community-based respondents (38.2\%). Similarly, results for the past 
one year use for learning institutions $(13.5 \%)$ was almost on par with that of community-based respondents (13.7\%). Such trends are disturbing considering that learning institutions are supposed to have policies that restrict the use of drugs hence contributing to the reduction in the likelihood of use. Similarly, most ADA prevention programmes target learning institutions for purposes of drug demand reduction. Such findings may be painting a grim picture in terms of how well PWDs benefit from such programmes. PWDs may not easily benefit from access to information on drugs due to their impairment. For example, the blind may require the brailing of Education and Communication (IEC) materials related to drug information, while the deaf may require a sign language interpreter to benefit from ADA prevention talks. The cost of making such special adaptations is high, and hardly any resources are currently allocated for such by the Kenyan Government. This calls for urgent intervention measures to address ADA prevention targeting the PWDs.

When compared with other findings of a study carried out in Kenya among the general public ${ }^{7}$ these findings show higher prevalence of several substances among PWDs. For example, 19.6\% of PWDs had used tobacco products compared to $17.3 \%$ of the general public while $14.8 \%$ had used khat (miraa/muguka) compared to $10.4 \%$ of the general public. Similarly $9.2 \%, 5.6 \%$ and $5.6 \%$ had used marijuana, heroin and cocaine respectively, which are all illicit drugs. These figures are a public health concern when compared with those of the general public which were at $5.4 \%$ for marijuana, $0.7 \%$ for heroin and $0.6 \%$ for cocaine. This shows that there is heavier drug use among PWDs particularly narcotics. In addition, some were using more than one substance. These high figures may be attributed to low awareness levels about the dangers of drug use as well as the illegality of certain drugs. These findings suggest that ADA interventions among PWDs need to pay particular focus on addressing the use of narcotics among other drugs considering that these are illicit drugs which could, in addition to the normal challenges of drugs, put PWDs in conflict with the law, thus complicating their existing vulnerabilities.

The study findings point to a need for efforts to address the high prevalence of drug use, particularly of narcotics, among PWDs. This calls for a need to question the accessibility of drug prevention materials to PWDs. In addition, considering that the findings also indicate that some PWDs use drugs daily, with some using multiple substances, there is a possibility of drug dependence, pointing to a need for PWDs to access treatment and rehabilitation services. This implies that there is need to look into the accessibility and affordability of treatment and rehabilitation services for PWDs, considering the barriers to treatment they may face, such as limited physical access as 
well as a lack of sensitivity to their unique needs by treatment and rehabilitation personnel.

The findings of this study have implications for the Kenyan Government and specifically the NACADA. They point to an urgent need for development of policies geared towards creating ADA prevention and treatment programmes that are focused and responsive to the unique needs of PWDs, as a way to promote their human rights and wellbeing as articulated in the Kenya Constitution (2010) and the Disability Act (2003).

\section{Limitation of the study}

In assessing the patterns of drug use, the researchers limited the definition of 'patterns of drug use' to types of drugs and the frequency of use, without looking at the specific quantities of drugs used. This was because it was felt that doing so would have been rather complex, considering that different drugs were being investigated which have varying means of quantification.

\section{Acknowledgement}

This research was supported by the Government of Kenya through a grant from the National Authority for the Campaign against Alcohol and Drug Abuse (NACADA). We acknowledge the support received from the NACADA technical team in carrying out the research.

\section{References}

1. National Campaign against Drug Abuse Authority (NACADAA). Rapid Situation Assessment of Drug and Substance Abuse in Kenya. 2007.

2. ILO/ Irish Aid Partnership Programme. Inclusion of People with Disabilities in Kenya. Fact sheet. 2009.

3. Government of Kenya. Disability Act. 2003.

4. Moore D, Greer G, Li L. Alcohol and other substance use/abuse among people with disabilities. Journal of Social Behaviour \& Personality. 2012;9(5) and 1994;369-382.

5. Government of Kenya. Alcoholic Drinks Control Act.2010.

6. National Campaign against Drug Abuse Authority (NACADAA) Fact Finding Mission. Report on the Extent of Alcohol and Drug Abuse in Central Province. 2009. 
7. National Authority for the Campaign against Alcohol and Drug Abuse (NACADA).Rapid Situation Assessment of the status of Drug and Substance Abuse in Kenya.2012.

8. National Campaign against Drug Abuse Authority (NACADAA). $\mathrm{Na-}$ tional Alcohol and Drug Abuse Research Workshop Report. 2011.

9. Fisher AA, Laing JF, Townsend JW. Handbook for Family Planning Operations Research Design, $2^{\text {nd }}$ Ed. 1998; New York. Population Council.

10. Cohen J. Statistical power analysis for the behavioral sciences, $2^{\text {nd }} \mathrm{Ed}$. 1988; NewYork: Academic Press.

11. Moore D, Li L. Disability and illicit drug use: An application of labeling theory. Deviant Behavior.2001; 22:1-21.

Doi: http://dx.doi.org/10.1080/016396201750065784

12. Kosterman R, Hawkins JD, Guo J, Catalano RF, Abbott RD. The dynamics of alcohol and marijuana initiation: Patterns and predictors of first use in adolescence. American Journal of Public Health.2000; 90(3):360-366.

Doi: http://dx.doi.org/10.2105/AJPH.90.3.360

13. Hollar D. Risk behaviors for varying categories of disability in NELS: 88. Journal of School Health, 2005;75(9):350.

Doi: http://dx.doi.org/10.1111/j.1746-1561.2005.tb06695.x

14. U.S. Department of Health \& Human Services Office of Disability. Substance Abuse and Disability: A Companion to Chapter 26 of Healthy People 2010.(internet) 2006a;

Available from http://www.hhs.gov/od/about/fact_sheets/substance abuse.html.

15. Janikowski TP, Lawrence JC, Donnelly JP. Functional limitations of clients with coexisting disabilities. Journal of Rehabilitation, 2007;73:15-22.

16. Koch DS, Dotson DG. Alcohol and other drug abuse as primary and co-existing disabilities. In J.D. Andrew and C.W. Faubion (Eds). Rehabilitation services. An introduction for human service professionals ( $\left.2^{\text {nd }} \mathrm{Ed}\right) .2008$; Osage Beech, MO:

Aspen Professional Services. 